\title{
Experd System Of Obesity Diagnosis Using Backward Chaining Method And Certain Factor
}

\author{
Fegie Y Wattimena ${ }^{1}$, Reni Koibur ${ }^{2}$, Dion R A Mamisala ${ }^{3}$, Septi Andryana ${ }^{4}$ \\ Faculty of Science and Technology,University Ottow Geissler Papua1,2,3 \\ Faculty of ICt , Universitas Nasional4 \\ Indonesia \\ e-mail: fegiywattimena.travel@gmail.com, rennykbr@gmail.com, \\ mamenshadow@gmail.com, septi.andryana@civitas.unas.ac.id
}

(APA style, Justify, Arial 10pt) Example:

To cite this document:

Wattimena, F., Koibur, R., Mamisala, D., \& Andryana, S. (2020). Experd System of Obesity Diagnosis Using Backward Chaining Method and Certain Factor. IAIC Transactions on Sustainable Digital Innovation (ITSDI), 1(2), 116-128.

https://doi.org/https://doi.org/10.34306/itsdi.v1i2.106

\begin{abstract}
Obesity is a medical condition in the form of excess body fat that accumulates in such a way as to have a detrimental impact on health, which then decreases life expectancy and or increases health problems. Obesity is now a common health problem in this modern society with a variety of technological discoveries that make people don't need to move a lot to do something, resulting in people living a lifestyle without much movement. Researchers feel the need for an expert system application that can easily diagnose obesity with everyone just by modulating simple applications on people's smartphones. The expert system that is built will diagnose early obesity disease by method of drawing inferences using backward chaining method and to test the level of belief conclusions using certainty factor method. The system will be able to provide output in the form of obesity diagnosis, explanation, tips and advice on obesity handling solutions. System development Methods using ESDLC (Expert System Development Life Cycle). The system is built on Android.
\end{abstract}

Keywords: expert system, obesity, Android, Backward Chaining, Certainty Factor

\section{Introduction}

In the midst of this rapid technological advancement, Indonesia will soon enter the Industrial 4.0 era. Industry 4.0 is an industry that combines automation technology with cyber technology. This is a trend of automation and data exchange in manufacturing technology. This includes cyber-physical systems, the Internet of Things (IOT), cloud computing and cognitive computing. Artificial Intelligence (Al) is part of cognitive computing, Al is artificial intelligence that is added to a system that can be arranged in a scientific context, a system like this is generally considered a computer. Intelligence is created and incorporated into a machine (computer) in order to do work like humans. Some fields that use artificial intelligence include Expert Systems, Robotics, Games, Fuzzy Logic and Artificial Neural Networks

Author Notification 22 March 2019 Final Revised 27 March 2019 Published 31 March 2019 
Expert systems are designed to be able to imitate experts in answering questions and solving a problem obtained from dialogue with users. With the help of an expert system someone who is not an expert can answer questions, solve problems and make decisions that are usually made by an expert.

The development of information technology is developing very rapidly along with the development of mobile phone or smartphone technology which continues to increase on a daily basis. The development of smartphone technology today has experienced many changes very rapidly, along with the increasing human needs and complex. Android smartphone which was originally only used by academics and the military, is now widely used in various fields, such as business, health, education, games and so on. This encourages experts to further develop Android smartphones in order to help human work or even exceed the ability of human work.

Obesity is a medical condition in the form of excess body fat that accumulates in such a way as to have a detrimental impact on health, which then decreases life expectancy and or increases health problems [1]. Obesity occurs when a large and increasing number of fat cells in a person's body. When a person gains weight, the size of fat cells will increase and then the number will increase. Obesity is a complex disorder of appetite regulation and metabolism energy which is controlled by several specific biological factors. Genetic factors are known to be very influential for the development of this disease. Physiologically, obesity is defined as a condition with abnormal or excessive accumulation of fat in adipose tissue thereby disrupting health. The impact of obesity results in an increase in other degenerative diseases such as diabetes mellitus, stroke to heart disease.

\section{Research Method}

Data Collection Methods In carrying out this research required data and related information which will be used as reference material for system design and support the validity of the discussion in the research report. As for the data collection methodology used in this research is :

Literature Study

Field Study and Literature and Documentation Study. Library Study This method is done by studying related theories that support problem solving for research consisting of 3 literatures from related journals. The journal used as material for this research study can be seen on the bibliography page of this research report.

Observation Field Study

This method is used for the purpose of obtaining information about the current system of public health consultation services at health centers or hospitals.

Documentation is a way of collecting data obtained from existing documents or records that are stored, whether in the form of transcript notes, books, newspapers, internet articles, and so forth.

The system development method used in this study is ESDLC (Expert System Development Life Cycyle). The systems development process has several stages. 


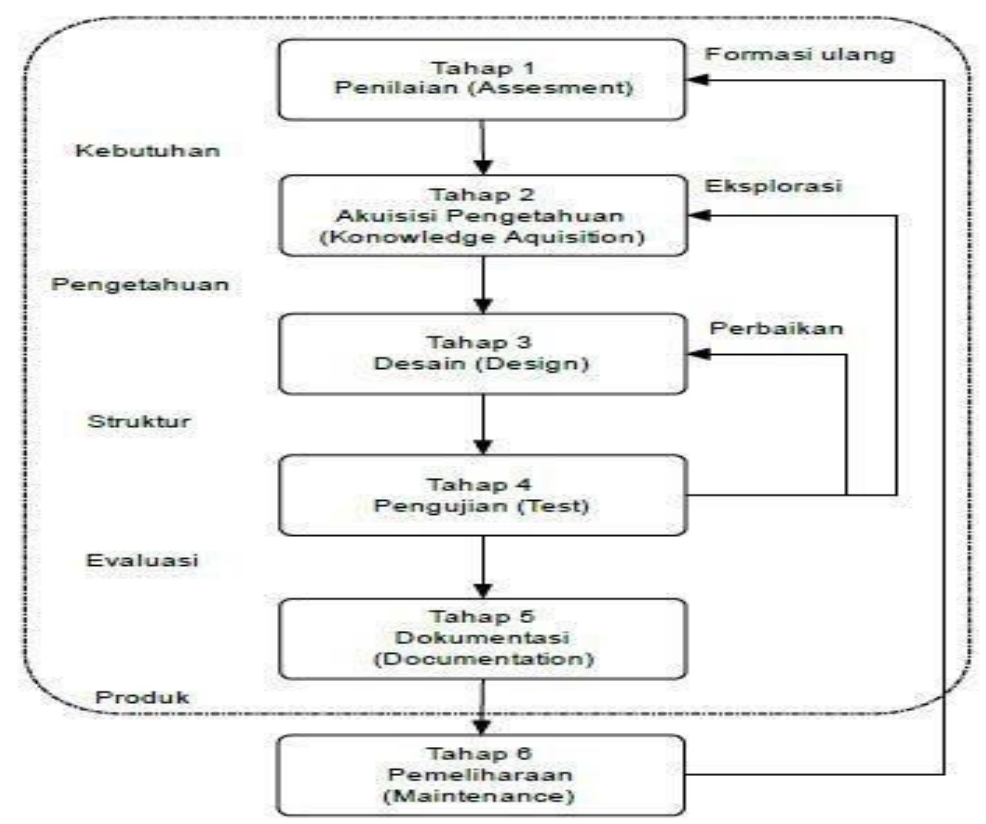

Figure 1. ESDLC

The following are the stages of ESDLC carried out in the development of expert systems:

a. Assessment

Stages of assessment carried out to determine important matters as the basis of the problem of diagnosis of Obesity. The steps taken are expertise, expert availability, software feasibility, obesity disease data collection.

b. Knowledge Acquisition

In the second stage after collecting the data the writer starts the acquisition process by changing the data of obesity symptoms into a knowledge base and expert system rules. The method used is the Backward Chaining method as the basis for making expert system rules as well as its inference method and Certainity Factor to measure the level of certainty of the results of the analysis.

c. The design

After the knowledge acquisition was successfully carried out, the researcher continued by making Database Design, Software Architecture Design and Interface Design. In designing database tools used are DFD and ERD as well as using Mysql software for database storage. The architecture design of the software uses Sublime Text3 software to process

the PHP programming language. The application interface design is made in a mobile

d. Testing display so that it can easily appear on an android phone.

The fourth stage in this ESDLC model is testing, before it can really be used properly by the user, the system must pass the testing stage first to ensure there are no obstacles that arise when the user uses the system. If the software system has finished passing the system testing stage, the software system is ready to use.

e. Documentation

The fifth step will be documented if an error code commonly appears in a software problem. 


\subsection{Formula/Algorithm [optional]}

Certainty Factor (CF) Formula :

\section{$\mathrm{CF}[\mathrm{H} . \mathrm{E}]=\mathrm{MB}[\mathrm{H}, \mathrm{E}]-\mathrm{MD}[\mathrm{H}, \mathrm{E}]$}

Information:

$\mathrm{CF}=$ Certainty Factor in the hypothesis $\mathrm{H}$ which is influenced by fact $\mathrm{E}$.

$\mathrm{MB}=$ Measure of Belief (confidence level), is a measure of the increase in the confidence of the hypothesis $\mathrm{H}$ influenced by fact $\mathrm{E}$.

MD = Measure of Disbelief (level of non-belief), is the belief of the unbelief of a hypothesis influenced by fact $\mathrm{E}$.

$\mathrm{E}$ = Evidence (event or fact)

$\mathrm{H}=$ Hypothesis (Guess)

$E=(E 1$ AND E2 AND E3) OR (E4 AND NOT E5)

The symptoms (E) Formula :

$E=\max \left[\min \left(E_{1}, E_{2}, E_{3}\right), \min \left(E_{4}-E_{5}\right)\right]$

The Body Mass index (BMI) Formula :

BMI = Weight in kilograms

Height in meters ${ }^{2}$

\subsection{Literature Review}

Research conducted by Nesi Syafitri and Alfred Apdian in 2018, Expert System for Diagnosing Obesity in Children Using the Backward Chaining Method, the purpose of this study is to create an Expert System to help doctors diagnose obesity in children and provide information to parents about therapy and symptoms of obesity based on heredity, physical activity and eating patterns, Expert System built Desktop Based.[2]

Research conducted Eful Saepullah and Dini Destiani Fatimah in 2017, Designing Expert System for Diagnosing Weight Problems in Adults using the Forward Chaining method. The aim of this study is to design an expert system for diagnosing weight problems in adults.[3].

Research conducted Fithry Tahel in 2018. Application of Experd System in children under five to detect obesity using the Case Based Reasoning method. The purpose of this study is to diagnose obesity in infants and assist doctors in diagnosing obesity in patients.[4]

\subsection{System Design}

System design method used is Data Flow Diagrams (DFD). Here is the DFD Expert System for Obesity Disease Diagnosis

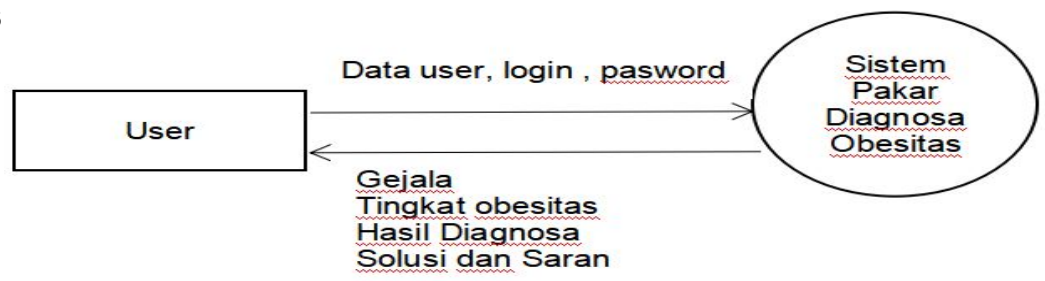


Figure 2. DFD Context SPDO

That in the Context Diagram above there is a User entity, the user will register and fill in the user's data then the system will process the diagnosis, the system will then provide information in the form of symptoms, obesity level, diagnosis results, solutions and suggestions to the user.

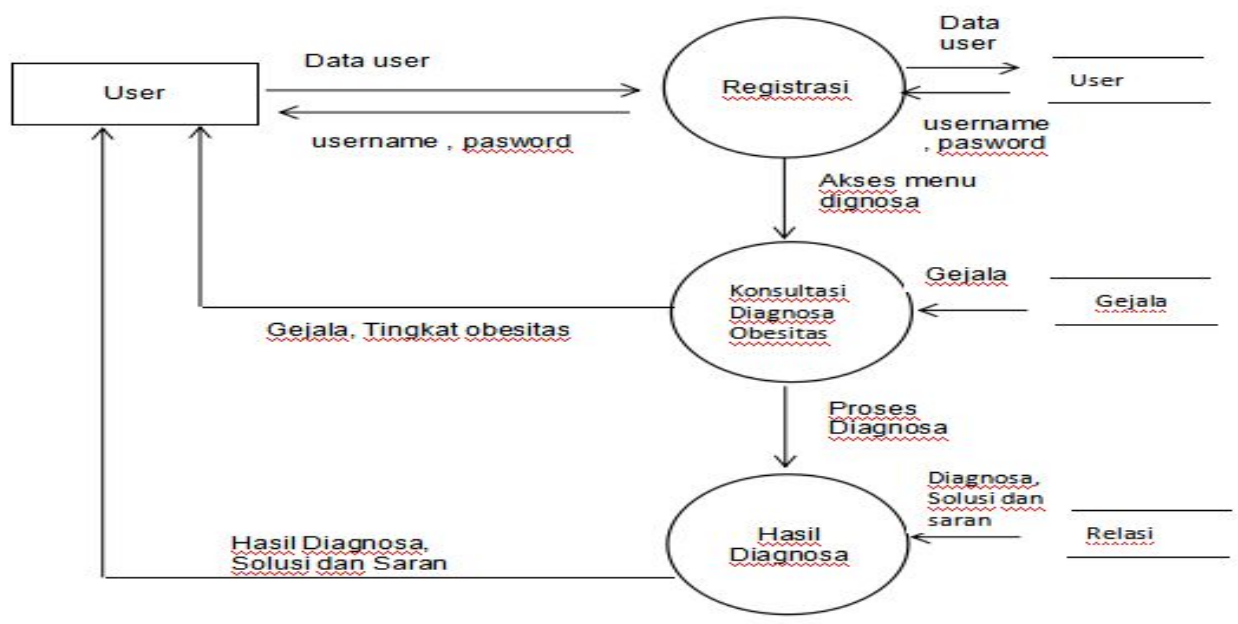

Figure 3. DFD Level 1 SPDO

That at DFD Level 1 in the process of registering user data will be stored in the User Table, the Registration Process will provide username and password information to the User, the Diagnostic Consultation Process will take symptom data from the symptom table and provide Symptom and Obesity level information to the user while the Diagnosis Results Process will take diagnosa data, solutions and suggestions from the relations table then provide information on the results of diagnosis solutions and suggestions to the user.

\section{Findings}

With the presence of an expert system to diagnose the disease obesity is expected to provide information to anyone about symptoms of obesity symptoms, as well as the criteria of obesity suffered and provide advice and solutions for prevention.

\subsection{Problem}

Lack of knowledge of the causes, initial symptoms, classification of obesity levels and medical solutions to obesity, there has not yet been an application of an android-based expert system that can help people diagnose obesity and the classification of obesity levels directly through personal smartphones.

Expert system which will be developed in this research can diagnose obesity without age limitation with 7 causative factors namely Physical, genetic, dietary, lifestyle, psychological, disease, and drug symptoms. This system can also measure the Body Mass index, the Obesity Level classification and provide medical treatment solutions to users based on Certain Factor values

Expert system that was built include:

a. User Home page namely Login and Registration

b. The Diagnosis Page is Measuring Body Mass Index (BMI) and Questionnaire for Obesity and Symptoms 
c. Information page contains: Health Advice / Tips, Obesity Explanation, Obesity Differences, Obesity Complications

d. Output in the form of Diagnosis Results, Level of Diagnosis and Health Suggestions to users.

\subsection{Research Implementation}

Knowledge acquisition for obesity is based on a knowledge base that is compiled based on the facts of obesity which are then converted into expert system rules with the backward chaining method.

Table 1. Symptoms Data Table

\begin{tabular}{|c|l|}
\hline Code & \multicolumn{1}{|c|}{ Symptoms } \\
\hline G1 & Often shortness of breath when doing light activities \\
\hline G2 & Often sleepy during the day \\
\hline G3 & Frequent sweating even if you are not exercising \\
\hline G4 & Often suffer from swelling in the legs and ankles \\
\hline G5 & There are family members who suffer from obesity \\
\hline G6 & $\begin{array}{l}\text { Father or mother is obese, or maybe both of your parents are } \\
\text { obese }\end{array}$ \\
\hline G7 & Irregular eating patterns \\
\hline G8 & Often eat fast food \\
\hline G9 & Often snacking \\
\hline G10 & Frequently consume foods high in calories \\
\hline G11 & often eat large amounts \\
\hline G12 & Frequent dinner or midnight (range at 10 pm - 3 am) \\
\hline G13 & Lack of exercise \\
\hline G15 & Not often active or do not move much to do activities \\
\hline G16 & Lack of sleep or irregular sleep \\
\hline G17 & Emotional conditions are often bad or bad mood \\
\hline G18 & Suffered from Prader Willi syndrome \\
\hline G19 & Suffers from Cushing's syndrome \\
\hline G20 & Suffered from Polycystic Ovary Syndrome \\
\hline G21 & Suffering from hypothyroidism \\
\hline G22 & Suffered from osteoarthritis \\
\hline G23 & Taking birth control pills \\
\hline G24 & Take antidepressants \\
\hline G25 & Taking antipsychotic drugs \\
\hline G26 & Take Anti Epilepsy drugs \\
\hline G27 & Take steroids \\
\hline G28 & Take Diabetes medication \\
\hline G29 & Take Beta-inhibiting drugs \\
\hline
\end{tabular}


Table 2. Cause Data Tables

\begin{tabular}{|c|l|}
\hline Code & \multicolumn{1}{|c|}{ Name of Cause } \\
\hline P1 & Physical symptoms \\
\hline P2 & Genetic \\
\hline P3 & Dietary habit \\
\hline P4 & Lifestyle \\
\hline P5 & Psychic \\
\hline P6 & Disease \\
\hline P7 & Drug \\
\hline
\end{tabular}

Table 3. Table Relationships Symptoms and Causes of Obesity

\begin{tabular}{|c|c|c|c|c|c|c|c|}
\hline Kode & P1 & P2 & P3 & P4 & P5 & P6 & P7 \\
\hline G1 & * & & & & & & \\
\hline G2 & * & & & & & & \\
\hline G3 & * & & & & & & \\
\hline G4 & * & & & & & & \\
\hline G5 & & * & & & & & \\
\hline G6 & & * & & & & & \\
\hline G7 & & & * & & & & \\
\hline G8 & & & * & & & & \\
\hline G9 & & & * & & & & \\
\hline G10 & & & * & & & & \\
\hline G11 & & & * & & & & \\
\hline G12 & & & * & & & & \\
\hline G13 & & & & * & & & \\
\hline G14 & & & & * & & & \\
\hline G15 & & & & * & & & \\
\hline G16 & & & & & * & & \\
\hline G17 & & & & & * & & \\
\hline G18 & & & & & & * & \\
\hline G19 & & & & & & * & \\
\hline G20 & & & & & & * & \\
\hline G21 & & & & & & * & \\
\hline G22 & & & & & & * & \\
\hline G23 & & & & & & & * \\
\hline $\mathbf{G} 24$ & & & & & & & * \\
\hline $\mathbf{G 2 5}$ & & & & & & & * \\
\hline G26 & & & & & & & * \\
\hline G27 & & & & & & & * \\
\hline G28 & & & & & & & * \\
\hline $\mathbf{G} 29$ & & & & & & & * \\
\hline
\end{tabular}

Table 4. Relationship between Symptoms and Physical Symptoms 


\begin{tabular}{|c|l|}
\hline Code & \multicolumn{1}{|c|}{ Symptoms } \\
\hline G1 & Often shortness of breath when doing light activities \\
\hline G2 & Often sleepy during the day \\
\hline G3 & Frequent sweating even if you are not exercising \\
\hline G4 & Often suffer from swelling in the legs and ankles \\
\hline
\end{tabular}

Table 5. Table of Symptoms and Genetic Relations

\begin{tabular}{|c|l|}
\hline Code & \multicolumn{1}{|c|}{ Symptoms } \\
\hline G5 & There are family members who suffer from obesity \\
\hline G6 & $\begin{array}{l}\text { Father or mother is obese, or maybe both of your parents } \\
\text { are obese }\end{array}$ \\
\hline
\end{tabular}

Table 6. Table of Relationship Symptomsand Eating Patterns

\begin{tabular}{|c|c|}
\hline Code & Symptoms \\
\hline G7 & Irregular eating patterns \\
\hline G8 & Frequent junk food (junk food) \\
\hline G9 & Often snacking \\
\hline G10 & Frequently consume high-calorie meals \\
\hline G11 & Eat often in large quantities \\
\hline G12 & Frequent dinner or midnight (range 10 - 3 am) \\
\hline
\end{tabular}

Table 7. Table of Relationship Symptoms and Lifestyle

\begin{tabular}{|c|l|}
\hline Code & \multicolumn{1}{|c|}{ Symptoms } \\
\hline G13 & Lack of exercise \\
\hline G14 & Do not often move or move a lot \\
\hline G15 & Lack of sleep or irregular sleep \\
\hline
\end{tabular}

Table 8. Symptoms and Psychological Relations Table

\begin{tabular}{|c|l|}
\hline Code & \multicolumn{1}{|c|}{ Symptoms } \\
\hline G16 & In Depression \\
\hline G17 & Emotional conditions are often bad or bad mood \\
\hline
\end{tabular}

Table 9. Relationship between Symptoms and Disease

\begin{tabular}{|c|l|}
\hline Code & \multicolumn{1}{|c|}{ Symptoms } \\
\hline G18 & Suffers from Prader Willi Syndrome \\
\hline G19 & Suffers from Cushing's Syndrome \\
\hline G20 & Suffered from Polycystic Ovary Syndrome \\
\hline G21 & Suffering from hypothyroidism \\
\hline G22 & Suffered from osteoarthritis \\
\hline
\end{tabular}

Table 10. Symptoms and Medication Relations Table

\begin{tabular}{|c|c|}
\hline Code & \multicolumn{1}{|c|}{ Symptoms } \\
\hline P28 & Taking birth control pills \\
\hline
\end{tabular}




\begin{tabular}{|l|l|}
\hline P29 & Taking antidepressants \\
\hline P30 & Taking Antipsychotic Drugs \\
\hline P31 & Taking antiepileptic drugs \\
\hline P32 & Taking steroids \\
\hline P33 & Taking Diabetes Medication \\
\hline P34 & Take Beta-Blocking Medications \\
\hline
\end{tabular}

\subsection{Display Program}

Main Page Display

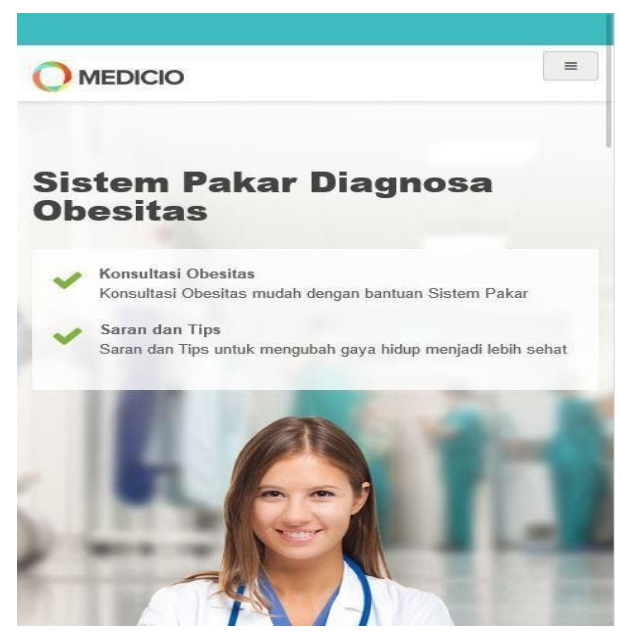

Display Page Login

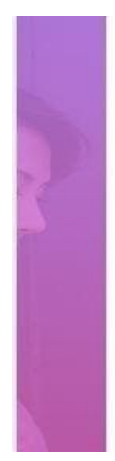

\section{Login}

Nama

Name

Password

Password

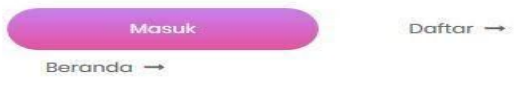

Figure 5. Login page 
Display Page Registrasi

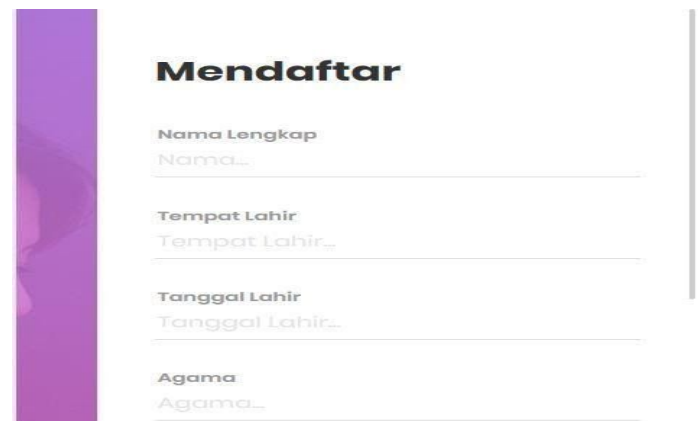

Figure 6. Registration Page

Display Page Suggestions and Tips

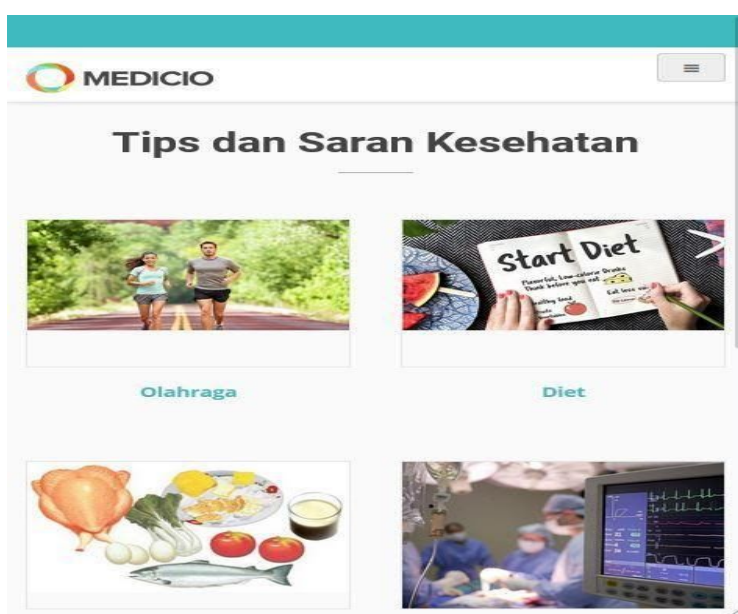

Figure 7. Health Advice and Tips Page

Display Home Menu Diagnosis

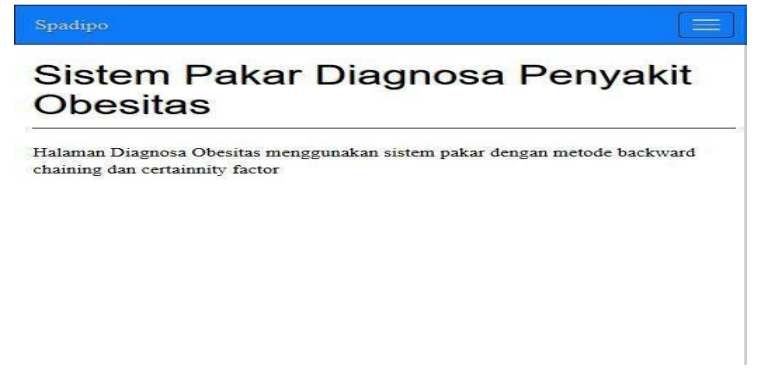

Figure 8. Home Menu Diagnosis 
Page Display List of Factors Cause

\begin{tabular}{|c|c|c|c|}
\hline \multicolumn{3}{|c|}{ Spadipo } & $\equiv$ \\
\hline \multicolumn{4}{|c|}{ Faktor Penyebab } \\
\hline No & Kode & Nama Diagnosa & \\
\hline 1 & P001 & Gejala Fisik & \\
\hline 2 & $\mathrm{POO} 2$ & Genetik & \\
\hline 3 & $\mathrm{POO}_{3}$ & Pola Makan & \\
\hline 4 & POO4 & Pola Hidup & \\
\hline 5 & Poos & Psikis & \\
\hline$\sigma$ & Poo6 & Penyakit & \\
\hline 7 & P007 & Obat & \\
\hline
\end{tabular}

Figure 9. Pages List of Factors Causing

G. Display Page List of Symptoms

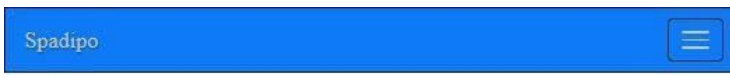

\section{Gejala}

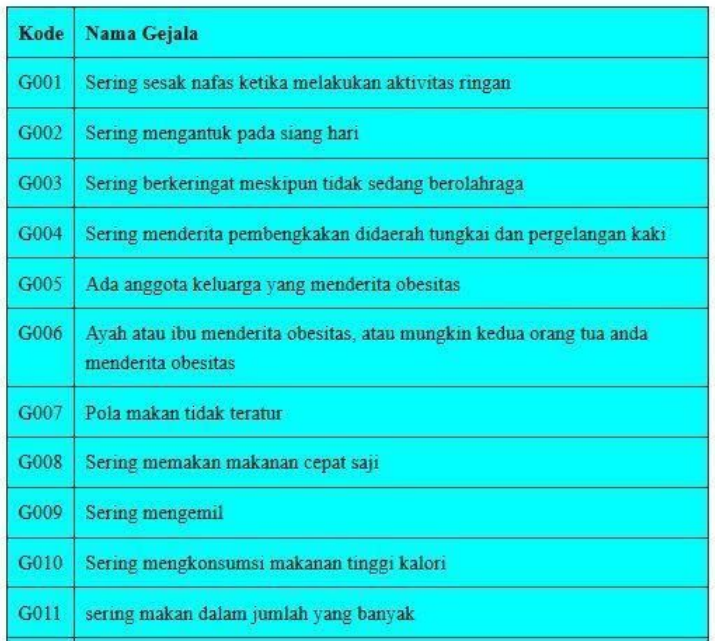

Figur 10. Page Daftar Gejala

H. Display of Stage I Diagnostic Pages 


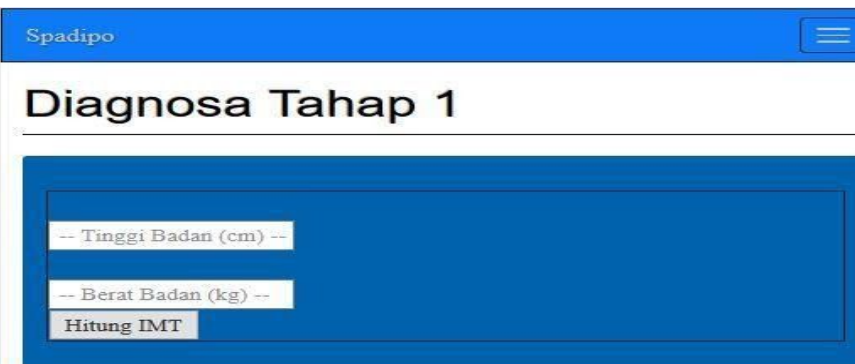

Figure 11. Stage I Diagnosis Page

Display of Phase II Diagnosis Results

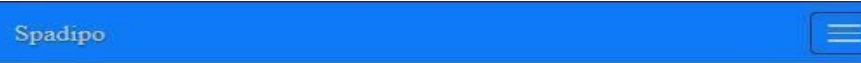

\section{Diagnosa Tahap 2}

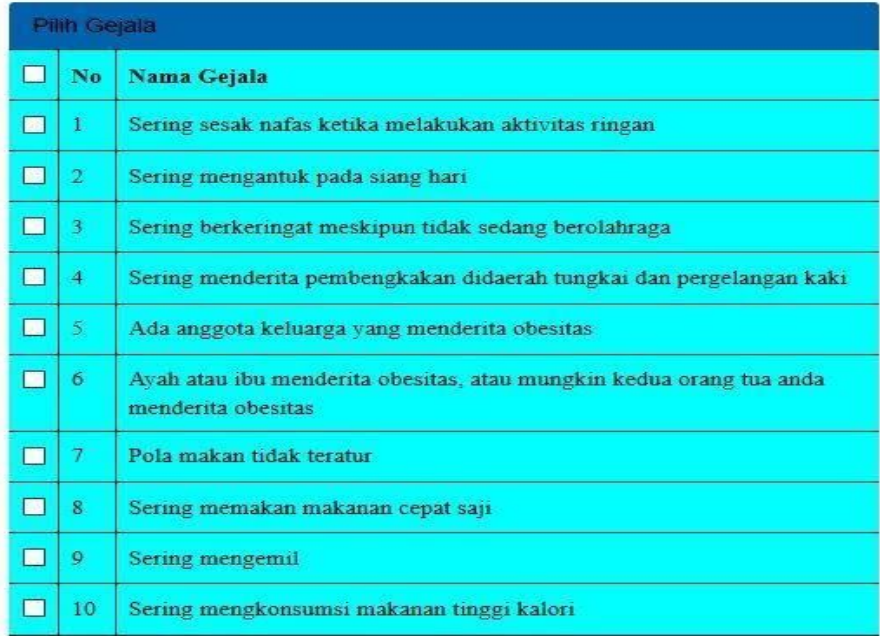

Figure 12. Stage II Diagnosis Page

Tampilan Halaman Hasil Diagnosa Tahap II 


\section{Spadipo}

\section{Hasil Diagnosa}

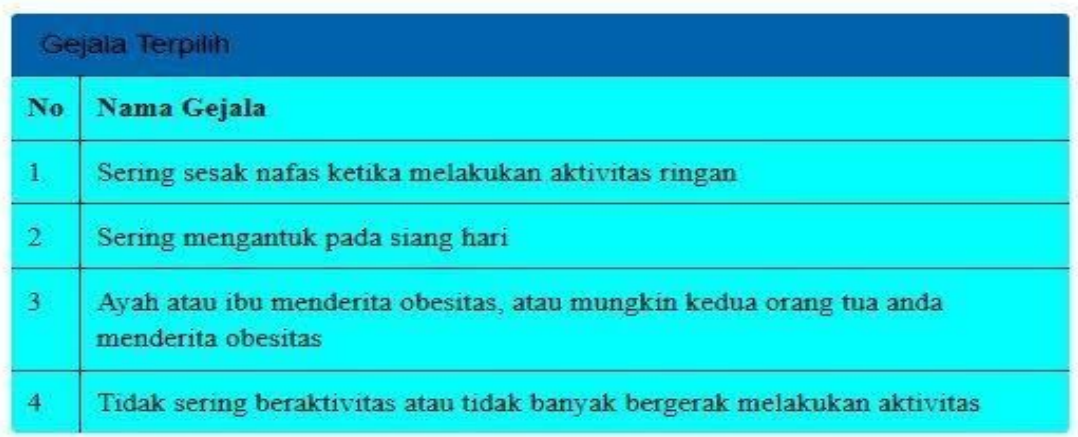

\begin{tabular}{|l|l|l|}
\hline \multicolumn{2}{|c|}{ Hasil Analisa } \\
\hline No & Diagnosa & Kepercayaan \\
\hline 1 & Genetik & 0.8 \\
\hline 2 & Gejala Fisik & 0.55 \\
\hline 3 & Pola Hidup & 0.5 \\
\hline
\end{tabular}

\begin{tabular}{|l|l|}
\hline Diagnosa & Genetik \\
\hline Solusi & $\begin{array}{l}\text { Faktor genetik adalah faktor yang asalnya dari orang tua. Sudah } \\
\text { diamati seiak lama hahwa anak-anak vang ohesitas seringkali }\end{array}$ \\
\hline
\end{tabular}

Figure 13. Phase II Diagnosis Results Page

\section{Conclusion}

This expert system for diagnosing obesity has been successfully built and helps users in:

1. Diagnose obesity without age restrictions

2. Classifying the level of obesity through measurement of BMI (Body Mass Index)

3. Determine the factors that cause obesity using the backward chaining method and provide medical treatment solutions to users based on the value of Certain Factors.

\section{References}

[1] Yahya, Nadjibah, ( 2017) . Kupas Tuntas Obesitas. Solo, Metagraf, 9 
[2] Syafitri, Nesi., Apdian, Alfred. (2016, July). Expert System to Diagnose Obesity in Children Using the Backward Chaining Method. It Journal Research And Development, 1(1), $1-8$.

[3] Saepullah, Eful., Fatimah, Dini Destiani. (2017). Expert System Design Diagnosis of Weight Problems in Adults. Algoritma Journal Sekolah Tinggi Teknologi Garut.

[4] Tahel, Fithry (2018). Application of Experd System in children under five to detect obesity using the Case Based Reasoning method. Journal Sistem Informasi Kaputama (JSIK), 2 (2) 